University of Nebraska - Lincoln

DigitalCommons@University of Nebraska - Lincoln

Post-harvest entomology research in the United States Department of Agriculture-Agricultural Research Service

James E. Throne

USDA-ARS, Manhattan, KS, james.throne@ars.usda.gov

Guy J. Hallman

USDA-ARS

Judy A. Johnson

USDA-ARS

Peter A. Follett

USDA-ARS

Follow this and additional works at: https://digitalcommons.unl.edu/usdaarsfacpub

Throne, James E.; Hallman, Guy J.; Johnson, Judy A.; and Follett, Peter A., "Post-harvest entomology research in the United States Department of Agriculture-Agricultural Research Service" (2003).

Publications from USDA-ARS / UNL Faculty. 2071.

https://digitalcommons.unl.edu/usdaarsfacpub/2071

This Article is brought to you for free and open access by the U.S. Department of Agriculture: Agricultural Research Service, Lincoln, Nebraska at DigitalCommons@University of Nebraska - Lincoln. It has been accepted for inclusion in Publications from USDA-ARS / UNL Faculty by an authorized administrator of DigitalCommons@University of Nebraska - Lincoln. 


\title{
Post-harvest entomology research in the United States Department of Agriculture-Agricultural Research Service ${ }^{\dagger \neq}$
}

\author{
James E Throne, ${ }^{1 *}$ Guy J Hallman, ${ }^{2}$ Judy A Johnson ${ }^{3}$ and Peter A Follett ${ }^{4}$ \\ ${ }^{1}$ US Department of Agriculture, Agricultural Research Service, Grain Marketing and Production Research Center, 1515 College Avenue, \\ Manhattan KS 66502, USA \\ ${ }^{2}$ US Department of Agriculture, Agricultural Research Service, Kika de la Garza Subtropical Agricultural Research Center, 2413 E Highway \\ 83, Building 200, Weslaco TX 78596, USA \\ ${ }^{3}$ US Department of Agriculture, Agricultural Research Service, San Joaquin Valley Agricultural Sciences Center, 9611 South Riverbend \\ Avenue, Parlier CA 93648, USA \\ ${ }^{4}$ US Department of Agriculture, Agricultural Research Service, US Pacific Basin Agricultural Research Center, Stainback Highway, Kulani \\ Road, Hilo HI 96720, USA
}

\begin{abstract}
This is a review of current post-harvest entomology research conducted by the Agricultural Research Service, the research branch of the US Department of Agriculture. The review covers both durable and perishable commodities. Research on biochemistry, genetics, physiology, monitoring and control of insects infesting stored grain, dried fruits and nuts, and processed commodities is reviewed. Research on development of quarantine treatments, particularly for fruit flies, is also reviewed, including research on thermal and irradiation treatments and a discussion of risk management for quarantine pests. Two areas of research are covered more extensively: a project to map the genome of the red flour beetle, Tribolium castaneum, and the use of near-infrared spectroscopy for detection of hidden infestations in grain, quantification of insect fragments in food, determination of quality in dried fruits, identification of insect species and age-grading insects. Future research directions are identified.

Published in 2003 for SCI by John Wiley \& Sons, Ltd.
\end{abstract}

Keywords: postharvest entomology; stored products; quarantine treatments

\section{OVERVIEW OF CURRENT RESEARCH}

This article reports on recent Agricultural Research Service (ARS) research on post-harvest entomology of durable and perishable commodities. Research on direct alternatives to the fumigant methyl bromide, such as the development of alternative fumigants and related technology, will be covered in the article on methyl bromide alternatives in this issue. In addition, research on post-harvest treatments of temperate perishables is covered in that article because methyl bromide fumigation has been a major quarantine treatment for these commodities. We review here the research on quarantine treatments for tropical and subtropical perishable commodities.

\subsection{Durable commodities}

The USA produces about 50 million tonnes of wheat and about 250 million tonnes of corn each year, with a total value of over $\$ 25$ billion. ${ }^{1}$ Damage caused by insects and other pests can exceed $\$ 1$ billion per year. ${ }^{2}$ Losses to processed commodities are more difficult to estimate, but exceed losses to raw grain. Processed commodities can suffer direct losses to product, as well as indirect losses such as lawsuits or loss of consumer confidence and resulting loss of purchases arising from contaminants in processed commodities, and also incur the costs of pest control.

Insect pests of stored grain can be separated into primary pests, those that can damage intact grain kernels, and secondary pests, those that cannot damage intact grain kernels. The major primary pest of corn in the USA is the maize weevil, Sitophilus zeamais Motschulsky (Coleoptera: Curculionidae). The major primary pests of wheat in the USA are the lesser grain borer, Rhyzopertha dominica (F) (Coleoptera: Bostrichidae) and the rice weevil, $S$ oryzae (L). The major secondary pests of corn and wheat in the USA are the red and confused flour beetles, Tribolium

* Correspondence to: James E Throne, USDA-ARS, GMPRC, 1515 College Avenue, Manhattan, KS 66503, USA

E-mail: throne@gmprc.ksu.edu

tOne of a collection of papers on various aspects of agrochemicals research contributed by staff of the Agricultural Research Service of the United States Department of Agriculture, collected and organized by Drs RD Wauchope, NN Ragsdale and SO Duke

\#This article is a US Government work and is in the public domain in the USA

(Received 9 May 2002; revised version received 18 September 2002; accepted 19 November 2002) 
castaneum (Herbst) and T confusum Jacquelin du Val (Coleoptera: Tenebrionidae); the sawtoothed grain beetle, Oryzaephilus surinamensis (L) (Coleoptera: Silvanidae); the flat and rusty grain beetles, Cryptolestes pusillus (Schönherr) and $C$ ferrugineus (Stephens) (Coleoptera: Laemophloeidae); and the Indianmeal moth, Plodia interpunctella (Hübner) (Lepidoptera: Pyralidae). Although secondary pests do not directly damage grain, they can cause heating of grain, and their presence can result in discounts in the price paid for grain. These same pests also infest processed commodities, although secondary pests are more common than primary pests in processed goods.

The USA dried fruit and tree nut industry, centered in the San Joaquin and Sacramento Valleys of central California, annually produces more than 1 million tonnes of commodity worth about $\$ 2.5$ billion. Used as out-of-hand snack foods or confectionery ingredients, dried fruits and nuts are relatively high value commodities. Export sales are of particular importance in the marketing of these products, with $30-80 \%$ of the production of almonds, walnuts, pistachios, raisins and prunes being sold for export.

Post-harvest pests of dried fruits and nuts may be divided into two broad categories: pests that infest product in the field and are brought into storage, and pests that infest product after it reaches storage. Field pests such as the navel orangeworm, Amyelois transitella (Walker) (Lepidoptera: Pyralidae), codling moth, Cydia pomonella (L) (Lepidoptera: Tortricidae), raisin moth, Cadra figulilella (Gregson) (Lepidoptera: Pyralidae) and dried fruit beetles, Carpophilus spp (Coleoptera: Nitidulidae) continue to damage product in storage, and may become regulatory issues in exported product. A variety of common storage beetles such as sawtoothed grain beetle, red flour beetle and Cryptolestes spp may infest dried fruits and nuts, but the most serious storage pest is the Indianmeal moth. The markets for post-harvest dried fruits and nuts typically have a much lower tolerance for insect infestation than markets for other durables, particularly in products destined for foreign markets.

During the second half of the 20th century, conventional insecticides were used routinely to protect durable commodities, and fumigants were used for remedial action. The dried fruit and nut industry continues to rely heavily on fumigation to disinfest both raw and finished products. Current research focuses on development of new types of control technologies, insecticides with minimal non-target effects, and integrated pest management programs that optimize use of all available control technologies. Research on post-harvest durable commodities is conducted by ARS in Gainesville, Florida; Manhattan, Kansas; and Parlier, California.

\subsubsection{Biochemical, genetic and physiological research}

Knowledge of the basic genetic regulation of insect growth and development may result in new control technologies. For example, Shippy $e t a l^{3}$ and Brown et $a l^{4}$ have shown that a gene hierarchy controls the development of mouthparts and other segmental appendages in insects, and that when certain of these genes or gene combinations are eliminated from the red flour beetle, mouthparts develop as legs or antennae (Plate 1). Embryos are thus unable to chew or feed, and die before hatching or soon after hatching. When more of the genes in this hierarchy are eliminated, most or all body segments sprout antennae (Plate 1), even those comprising the abdomen, and the embryos are so extensively malformed that they invariably die before completing development. Thus, this gene hierarchy potentially may be manipulated for control purposes, which would result in premature death of insects.

The insect immune system is highly adapted for protection against potential pathogens and attack by parasitoids. In order for an effective immune response to be elicited, an initial recognition event that signals an impending threat is required. A $\beta$-1,3-glucan recognition protein $(\beta-\mathrm{GRP})$, one key protein in the immune system of the Indianmeal moth, has been purified from larval hemolymph. A cDNA encoding this protein has also been cloned, sequenced and expressed in Escherichia coli and baculovirus heterologous expression systems (Fabrick, Baker and Kanost, pers comm). Both the intact $\beta$-GRP and its $N$-terminal domain bind to carbohydrates, which are also found in the cell walls of invading microorganisms, and induce aggregation of micro-organisms in laboratory studies (Plate 2). This aggregation is significant because the large aggregates of foreign material may provide a better target for both cellular and acute-phase humoral responses. The latter humoral responses include the signaling and production of antimicrobial peptides that attack the invading micro-organism, as well as the initiation of the prophenoloxidase activating system. Activation of prophenoloxidase is one of the major immune responses in insects and may result in melanotic encapsulation, production of toxic quinones that may be involved in the death of invading organisms, and/or opsonization (a signaling mechanism resulting in recruitment of phagocytic hemocytes that enhance removal of invading organisms from the hemolymph). Knowledge about insect immunity not only allows a better understanding of how insects overcome attack by specific biopesticides, but also may provide insight into means of overcoming those responses, making insects more susceptible to selected biologically based control methods.

Inhibition-rescue studies involving the release of the substrate arachidonic acid from membranebound phospholipids have demonstrated a role for eicosanoids in mediating insect cellular immune responses to various bacteria. ${ }^{5}$ Lord (pers comm) has demonstrated that eicosanoids play a role in the nodulation and phagocytosis of Beauveria bassiana (Balsamo) Vuillemin, an entomopathogenic fungus. $\mathrm{He}$ also determined that, of the three oxidative pathways for eicosanoid synthesis from arachidonic 


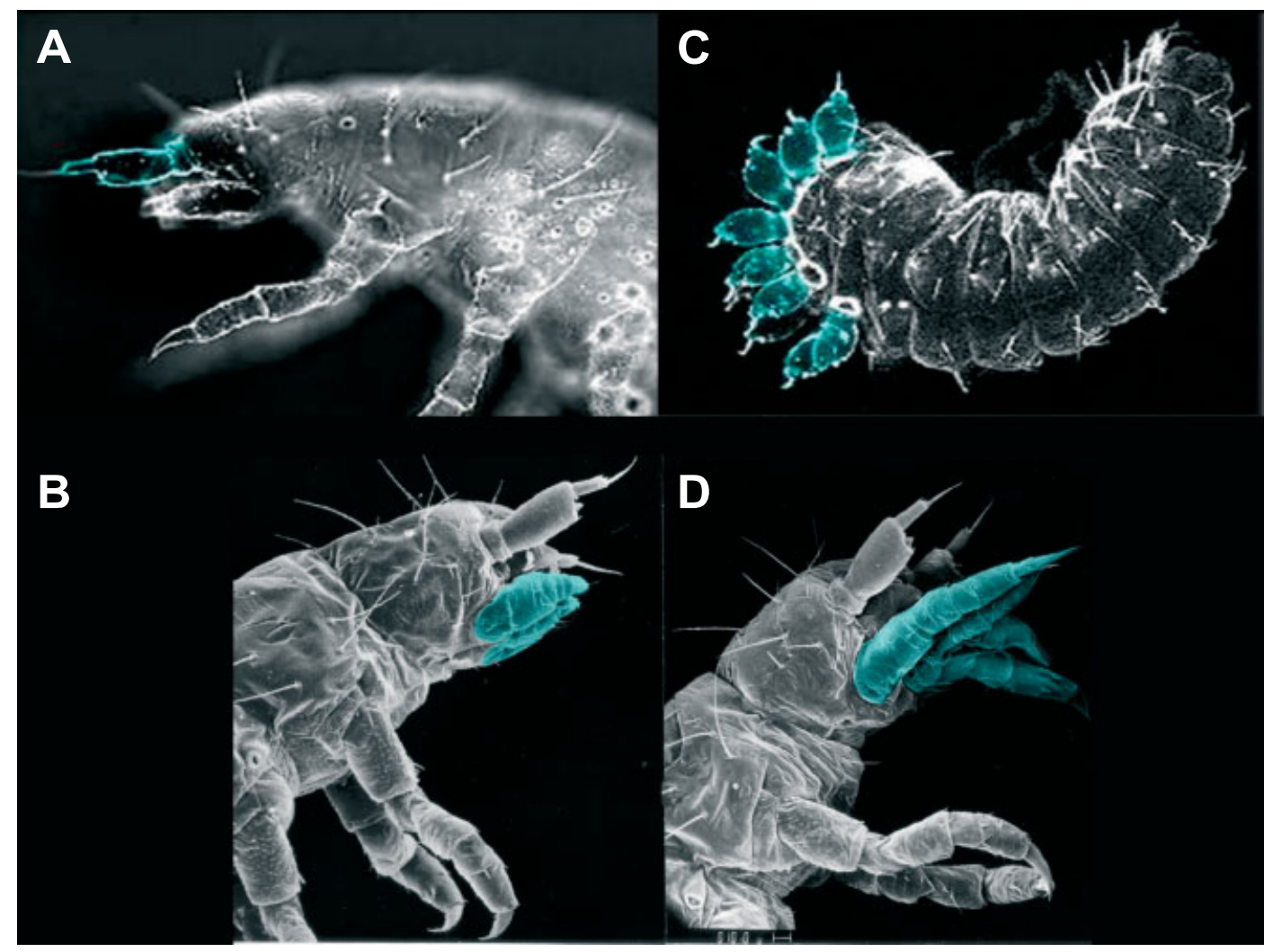

Plate 1. Red flour beetle larvae highlighting (A) normal antenna and (B) normal palpi, and larvae genetically modified to produce (C) antennae on the head and all thoracic segments and (D) legs in place of palpi.
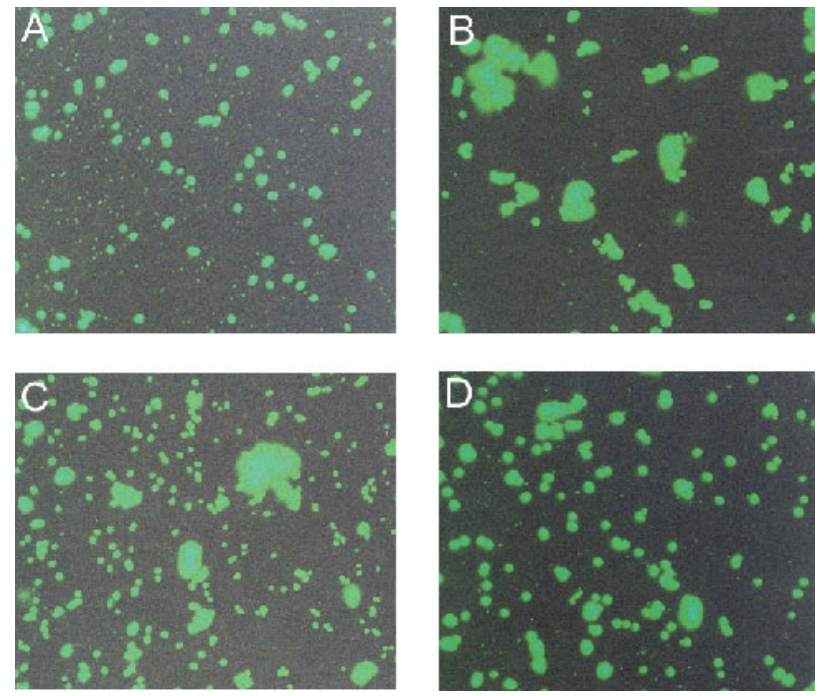

Plate 2. In vitro aggregation of fluorescein-conjugated Saccharomyces cerevisiae by recombinant Plodia interpunctella $\beta$-1,3-glucan recognition protein ( $\beta$ GRP) and its domains. Yeast particles were resuspended in phosphate buffered saline $\left(1 \times 10^{8} \mathrm{cells} \mathrm{ml}^{-1}\right)$ and incubated at room temperature for $30 \mathrm{~min}$ with (A) $0.05 \mathrm{mg} \mathrm{ml}^{-1}$ bovine serum albumin, (B) intact recombinant $\beta \mathrm{GRP}$, (C) recombinant $\mathrm{N}$-terminal $\beta$ GRP domain, or (D) recombinant C-terminal $\beta$ GRP domain. Samples of the cells were applied to a microscope slide and observed using fluorescence microscopy. 
EGPIC Ver. 6

B- NYLON 6/6 SERIES PROBE U.S. PATENT No. 5,646,404

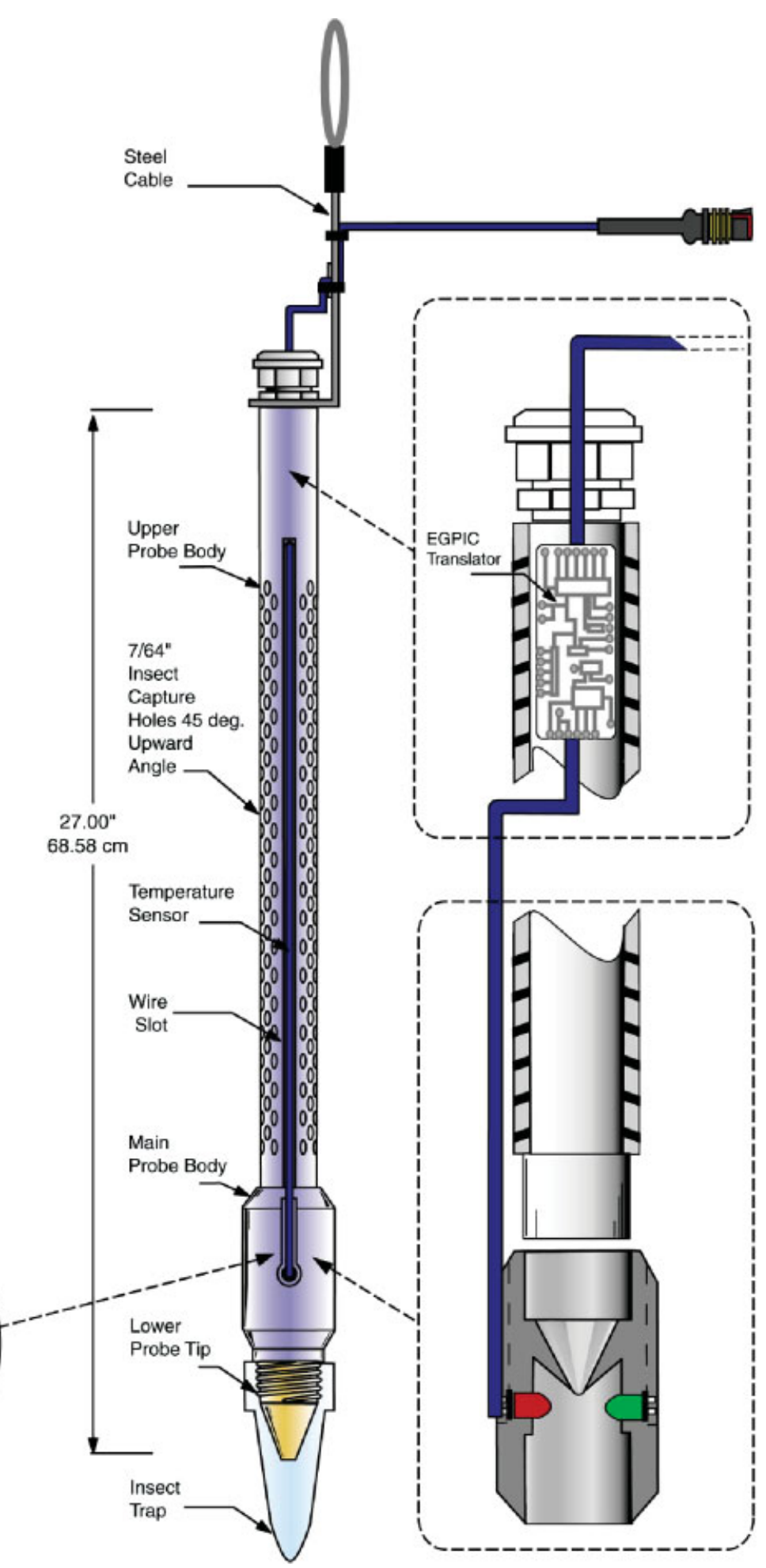

Plate 3. EGPIC (Electronic Grain Probe Insect Counter) probe trap with cut-away view of insect falling through infrared beam. 
acid, the lipoxygenase cascade produces the signal molecules for $B$ bassiana nodulation. Although there is previous evidence for the presence of lipoxygenase products in insects, this is the first function to be assigned to them.

Learning more about how the insect exoskeleton or cuticle is formed and recycled during molting has led to new methods for controlling insects, such as the use of insect growth regulators that disrupt molting, ${ }^{6}$ and could lead to other new control methods. ${ }^{7}$ Kramer and collaborators have characterized reactants, ${ }^{8}$ intermediates, ${ }^{9}$ products ${ }^{10}$ and enzymes responsible for cuticle tanning, ${ }^{11}$ including several new catecholamine metabolites, ${ }^{12}$ structural proteins ${ }^{13}$ and carbohydrates, ${ }^{14}$ and enzymes that participate in cuticle cross-linking and molting reactions. ${ }^{15,16}$ They also have conducted solid-state NMR analysis of intact cuticles to determine the compositional changes and molecular interactions that occur during cuticle stabilization in vivo. ${ }^{10}$ This work led to the patenting of the gene for the insect molting enzyme chitinase for biopesticidal applications, ${ }^{17}$ and this transgene is now being inserted into corn, rice, sorghum and wheat plants to provide control of both field and storage pests. ${ }^{18,19}$

There are many proteins that occur in nature that are potential biopesticides. Morgan et $a l^{20}$ showed that avidin, which is found in chicken egg white, kills several species of stored-product insects when administered in diets. Avidin kills insects by sequestering the vitamin biotin. Since that initial work, Prodigene, Inc (College Station, TX) has incorporated a gene that produces avidin into corn plants, ${ }^{21}$ and the avidin corn is toxic to and prevents development of over 30 species of insects that have been tested. ${ }^{22,23}$ Only one species of insect tested, the larger grain borer, Prostephanus truncatus (Horn) (Coleoptera: Bostrichidae), has exhibited tolerance to avidin. Symbiotes that live in the gut of larger grain borers may produce biotin, resulting in tolerance by this species. Avidin is unique as a biopesticide in having an antidote. Insects develop normally when biotin is added to a diet containing avidin. As well as having commercial potential as insect-resistant crops, avidin grains may be useful as a background insecticide in transgenic crops producing other desirable products or may be useful when ground and applied as an insecticidal dust formulation.

\subsubsection{Monitoring}

Estimating insect population levels is an essential component of integrated pest management programs. Probe traps are used to capture insects moving through grain, but these traps need to be serviced by someone entering the grain bin, which is labor-intensive, limits the temporal availability of the data and presents a potential confined-space entry hazard. An automated system has been developed that counts insects as they fall through an infrared beam in the probe trap (Plate 3), and time-stamped insect counts are automatically sent to a computer. ${ }^{24-26}$ Technology is now being developed to identify insects falling through the infrared beam based on size of the insects. The system is being commercially developed with OPI Systems in Calgary, Canada. Research is also underway to develop new acoustic sensor systems to facilitate automated detection of hidden insect infestations in packaged commodities. ${ }^{27}$

Traps also are routinely used in processing plants, warehouses and retail outlets to monitor insect populations. The standard trap used for beetles is a pitfall trap, the Flit-Trak ${ }^{\mathrm{TM}}$, that can incorporate a food-oil bait and/or a pheromone lure. ${ }^{28}$ The trap is effective, but is susceptible to becoming clogged with dust when used in dusty environments. The Dome $^{\mathrm{TM}}$ trap is a modification of the Flit-Trak that was modified for use in dusty environments by adding a dome-like cover. Moths are monitored using sticky traps; ${ }^{29}$ however, the presence of traps containing dead insects is unsightly and may be a deterrent to use of these traps in retail stores. Hence, a hidden flight trap, the Discreet ${ }^{\mathrm{TM}}$ trap, was developed. ${ }^{30}$ This trap is designed to be located under shelves and out of sight. Trécé, Inc (Salinas, CA) markets both the Discreet ${ }^{\mathrm{TM}}$ and Dome ${ }^{\mathrm{TM}}$ traps.

Making pest management decisions based on trap catches is not straightforward. One tool that has been developed to aid this process is the use of contour mapping for identifying foci of infestation and for precision targeting of control technologies. ${ }^{31}$ For example, contour analysis of trap catches in retail stores identified infested products that served as sources of infestation for other products in the stores, and the contour maps readily showed effects of control measures on insect populations. ${ }^{32}$ The method was also used to locate pest concentrations in bagged dried botanicals stacked on pallets in warehouses (Fig 1) and enabled the warehouse manager to fumigate only the infested commodity, rather than the entire warehouse. ${ }^{33}$

\subsubsection{Control technologies}

Recent biological control research has focused on interactions of natural enemies with other control technologies. Parasitization rates by Anisopteromalus calandrae (Howard) (Hymenoptera: Pteromalidae) of rice weevils were reduced on wheat treated with diatomaceous earth (DE). ${ }^{34}$ The number of weevils emerged increased with increasing dose of DE because of the reduction in rate of parasitization. Conversely, DE has a synergistic effect on efficacy of $B$ bassiana for control of several stored-product beetles. ${ }^{35}$ However, the parasitoid Cephalonomia tarsalis (Hymenoptera: Bethylidae) is adversely affected by $B$ bassiana, ${ }^{36}$ indicating that the two natural enemies should not be used together.

Current work with insecticides focuses on insecticides with minimal non-target effects, such as insect growth regulators, ${ }^{37,38}$ kaolinite-based particle films (Arthur, pers comm) and neo-nicotinoids (Arthur, pers comm), and on optimizing insecticide efficacy 


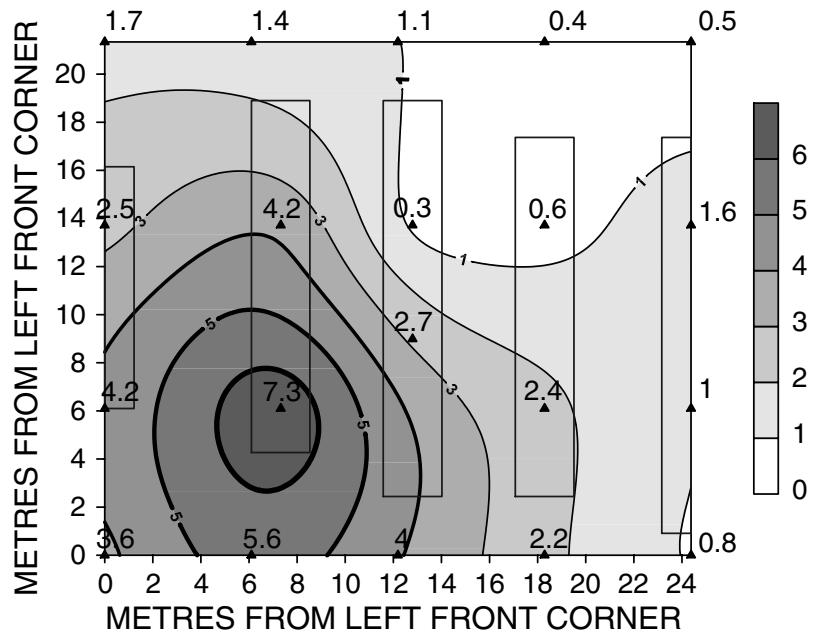

Figure 1. Spatial distribution of Indianmeal moths in a botanicals warehouse in North Carolina, as indicated by the average daily capture rate over a 10-day period (15-25 September 1998) in SP-Locator Traps baited with SP Minimoth pheromone dispensers (Agrisense-BCS Ltd, Pontypridd, Mid Glamorgan, UK). The rectangles represent steel shelf units holding a wide variety of dried plant materials in bags, boxes and drums. Trap positions are indicated by triangles. The moths were present throughout the warehouse, but captures were concentrated in an area containing poke root and witch hazel bark. It wasn't possible to examine these materials for infestation, but the need for treatment of this area or of removal and treatment of the materials in the area is clearly indicated.

by determining effects of food or debris that might be found in a processing facility and environmental conditions on efficacy. ${ }^{39,40}$ Other control technologies being investigated are resistance of commercial corn hybrids (Throne and Baker, unpublished data), commercial oat cultivars, ${ }^{41}$ and Tripsacum-Zea diploperennis hybrids ${ }^{42}$ to storage insect pests; insect-resistant packaging; ${ }^{43}$ low temperature storage; ${ }^{44}$ radio frequency heat treatments; ${ }^{45}$ and vacuum treatments (Zettler, pers comm). Integrated pest management systems that combine the use of several treatments have been shown to be effective in preventing infestation of walnuts, almonds, and raisins without using fumigants. ${ }^{46,47}$ These systems combine a relatively short-term low oxygen treatment to disinfest incoming product with a variety of protective treatments (low temperature, low oxygen, entomopathogenic virus) (Fig 2). The Indianmeal moth granulosis virus has been patented ${ }^{48}$ and is being commercially developed as a protectant insecticide, with initial uses intended for dried fruit and nuts. In addition, winter releases of the parasitoid Habrobracon hebetor (Say) (Hymenoptera: Braconidae), which paralyzes and parasitizes diapausing Indianmeal moth throughout the winter in California, ${ }^{49}$ are being used to reduce spring moth emergence in stored nuts (Johnson and Valero, pers comm).

\subsubsection{Computer-aided decision making tools}

Computer models have been developed for some of the major pests of stored corn, ${ }^{50-52}$ wheat $^{53}$ and processed commodities, ${ }^{54}$ and for some of the natural
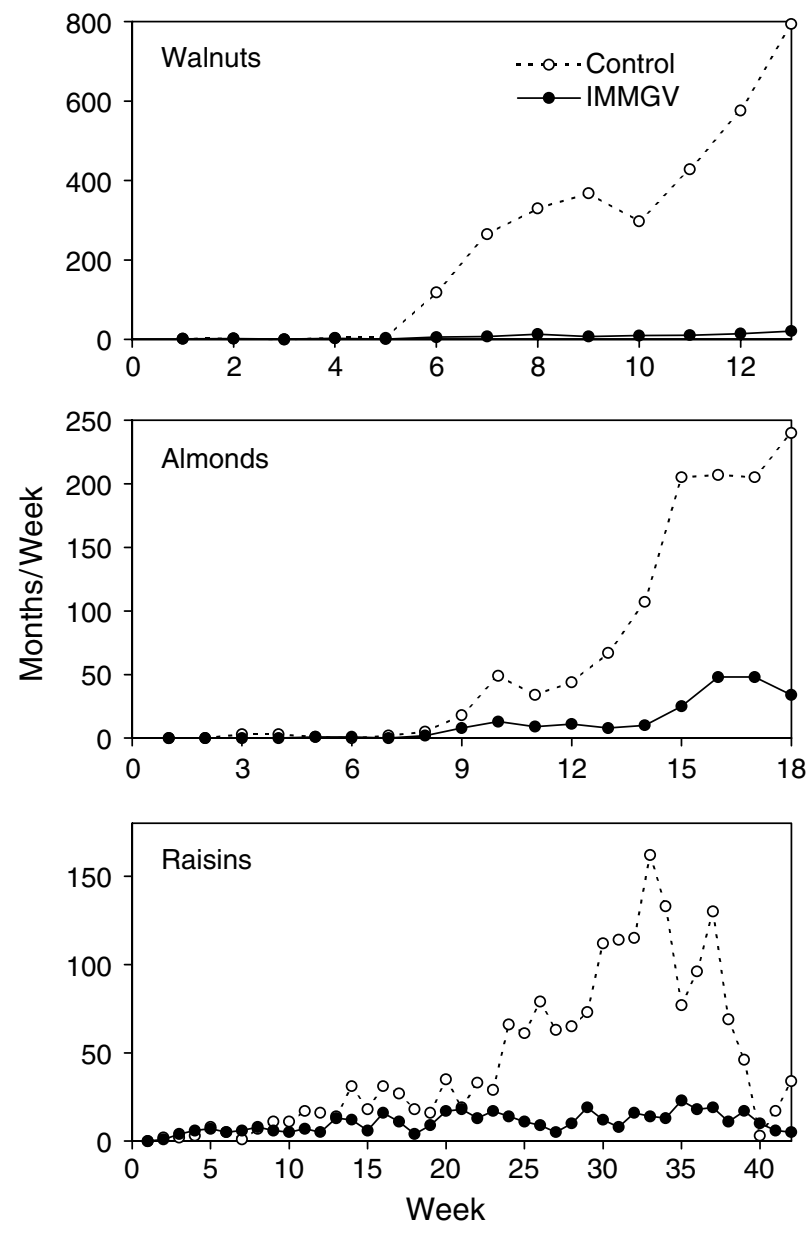

Figure 2. Indianmeal moths caught in pheromone traps placed in dried fruit or nuts treated with a protectant containing Indianmeal moth granulosis virus (IMMGV) or left untreated (Control). Very few moths were recovered from similar treatments using low oxygen or low temperature and were not included in the graphs. The drop in the number of moths caught in untreated raisins after 35 weeks was due to parasitization by Habrobracon hebetor.

enemies of these pests. ${ }^{55,56}$ These models have been used to help optimize control technologies in these commodities and to develop an expert system to aid in management of insect pests in farm-stored wheat. ${ }^{57}$ The expert system is currently being extended to develop a risk analysis program to aid in management of insect pests of wheat stored in elevators, and the risk analysis program is being tested as part of an areawide integrated management program for insect pests of wheat. ${ }^{58}$

\subsection{Perishable commodities}

Unlike durables, arthropods do not cause appreciable damage to fresh fruits and vegetables after harvest. This is because pathogens generally will destroy perishable commodities before arthropods have that opportunity, and because fresh produce is usually stored at low temperatures below the developmental threshold for arthropods. However, arthropods are a major concern to the marketability of fresh commodities because of quarantine regulations. Commodities that pose a risk of being infested, even at a very low level, 
with pests that are not established in areas where the commodities might be shipped must be subjected to a quarantine treatment that lowers the risk to negligible levels. ${ }^{59}$

Importation of tropical and subtropical perishables into the USA increases steadily in response to consumers' curiosity and desire for exotic fruits, vegetables and ornamentals, and to satisfy ethnic groups in the country already familiar with these items. Many of these products must be treated to avoid importation of quarantine pests. For example, all of the 220000 tonnes of mangoes imported into the USA in 1999 were dipped in water at $46^{\circ} \mathrm{C}$ to kill tephritid fruit fly eggs and larvae. Many imported perishables are fumigated with methyl bromide or stored at temperatures near freezing for many days in order to kill quarantine pests. ${ }^{60}$

Tropical tephritid fruit flies, such as the Mediterranean fruit fly, Ceratitis capitata (Wiedemann), and the West Indian fruit fly, Anastrepha obliqua (Macquart), are quarantine pests of primary concern for imports into the USA. A few examples of exotic pests from other taxonomic groups that might infest imported tropical and subtropical commodities are the light brown apple moth, Epiphyas postvittana (Walker) (Lepidoptera: Tortricidae), the false spider mite, Brevipalpis chilensis Baker (Acari: Tenuipalpidae) and the yellow tea thrips, Scirtothrips dorsalis Hood (Thysanoptera: Thripidae). The ARS studies exotic pests to prevent their establishment in the USA, to provide access to exotic produce for consumers, and because parts of the USA and its territories are infested with these pests. This research has been conducted in Hilo, Hawaii, and Weslaco, Texas, for many years, and new programs on pest exclusion and eradication have been initiated in Fresno, California, and Miami, Florida.

\subsubsection{Hawaii}

An average of 15 species of exotic insect invades Hawaii each year; approximately 2700 of the 8000 species of insects catalogued from Hawaii were accidentally introduced. The state is a stepping-stone to the USA mainland for exotic pests. Fruits and vegetables grown in Hawaii are subject to federal quarantine regulations because of four pest tephritid fruit flies-Mediterranean fruit fly; oriental fruit fly, Bactrocera dorsalis (Hendel); melon fly, B cucurbitae (Coquillet); and the solanaceous fruit fly, $B$ latifrons (Hendel) - and other pests. Hawaii has quarantine treatments (heat, cold, irradiation or non-host status) for 13 fruits and five vegetables. In all cases, except sweet potatoes, quarantine treatments were developed against tephritid fruit flies. Although fruit flies are some of the most important quarantine pests, other regulatory arthropod pests infest Hawaii's fresh fruits and vegetables and have equal status with fruit flies in interrupting export shipments. Quarantine research must consider the entire pest complex. Commodities infested with internally feeding pests are particularly important because these pests may be difficult to find via visual inspection. An examination of three quarantine pests, two Cryptophlebia spp and the mango seed weevil, Sternochetus mangiferae F (Coleoptera: Curculionidae), illustrates the approaches being taken to ensure quarantine security in fruit exports from Hawaii.

Lychee, longan and rambutan (Sapindaceae) are the main crops in a rapidly expanding tropical specialty fruits industry in Hawaii. All three fruits are attacked by two tortricid pests - the koa seedworm, Cryptophlebia illepida Butler, a native Hawaiian species, and the litchi fruit moth, Combrodelta (Lower), an Australian import-in addition to fruit flies. Irradiation at a minimum absorbed dose of $250 \mathrm{~Gy}$ is a treatment approved by APHIS (US Department of Agriculture, Animal and Plant Health Inspection Service) for disinfestation of fruit flies in all three fruits, and hot water immersion at $49^{\circ} \mathrm{C}$ for $20 \mathrm{~min}$ is an accepted fruit fly treatment for lychee and a proposed treatment for longan. In all cases, the treatment protocol requires that fruits are inspected and found free of Cryptophlebia. Recent studies showed that fruit fly treatments consisting of forced hot air and irradiation were also effective against Cryptophlebia. ${ }^{61,62}$

The mango seed weevil is a quarantined pest that prevents the shipment of mangoes from Hawaii into the continental USA. Mango seed weevil feeds only on mango. The high-risk quarantine pest status given to it is mainly in response to concerns from the mango industry in Florida that mango seed weevil infestation will reduce seed germination and limit seed production in nurseries and orchards. A study of premature fruit drop showed that the seed infestation rate was significantly higher in fruit collected off the ground compared with fruit collected off the tree, suggesting that mango seed weevil infestation can increase fruit drop in early season mangoes. ${ }^{63}$ Germination rates for infested seeds were equal to those of uninfested seeds in a polyembryonic cultivar 'Common', whereas germination was significantly reduced for seeds of the monoembryonic cultivar 'Haden' ${ }^{64}$ Over a 2 -year period, only $0.29 \%$ of mango fruits showed evidence of direct feeding damage to the pulp. Results from these studies suggest that $C$ mangiferae is a less serious pest of mangoes than was previously thought. One hundred Gy was found to sterilize mango seed weevil in tests with a few thousand weevils, ${ }^{65}$ and a proposed rule recommends a minimum absorbed dose of $100 \mathrm{~Gy}$ as a quarantine treatment. ${ }^{66}$

Thermal death kinetics has been used to characterize the thermotolerance of a number of tephritid fruit fly species of quarantine importance, and these data have been entered into a growing global database that can be used to establish whether a new invasive fruit fly species can be controlled with accepted heat treatments. ${ }^{67}$ For example, $B$ latifrons was discovered in Hawaii in 1983 and 
became a pest of quarantine significance in pepper, tomato and eggplant. Comparison of thermal death kinetics of $B$ latifrons with other tephritid fruit flies present in Hawaii revealed this species to be more resistant to heat than Mediterranean fruit fly, oriental fruit fly or melon fly, suggesting that quarantine heat treatments developed against these species might not be adequate to control $B$ latifrons.

\subsubsection{Texas}

Post-harvest quarantine treatment research at Weslaco has traditionally focused on the Mexican fruit fly, which is endemic to extreme southern Texas, and on other fruit flies existing in Mexico. But, because Weslaco is the easternmost ARS laboratory doing market access research, the laboratory also conducts research on pests infesting east-coast exports, whether they are interstate or international.

Following studies in the early to mid-1990s to control fruit flies with forced, heated air, which led to a treatment for oranges, tangerines and grapefruits from Mexico, ${ }^{60}$ attention was turned to heat combined with low oxygen. Mortality is achieved in a shorter time when heat is applied in hypoxic versus ambient atmospheres. ${ }^{68}$ Optimum temperature for grapefruit treatment at $500 \mu \mathrm{l}$ litre $^{-1}$ oxygen was $14-16^{\circ} \mathrm{C}$. Although higher temperatures shortened the time to achieve complete Mexican fruit fly mortality, they also caused unacceptable damage to fruits. Still, complete egg mortality (the most tolerant stage) did not occur after 18 days of treatment. Future research is directed toward understanding why a small percentage of the eggs survive long treatment times.

The hot water treatment for mangoes from Mexico was recently re-examined after live Mexican fruit fly larvae were found in treated fruits. ${ }^{69}$ It was found that rapid post-treatment cooling of heated mangoes plus heating of oversized mangoes may have been responsible for surviving insects, and recommendations restricting speed of cooling and size of mangoes were made. Further research is aimed at providing a hot water treatment for mangoes $>0.7 \mathrm{~kg}$, which cannot be shipped under current treatment protocols. ${ }^{70}$

Ionizing radiation is a quarantine treatment that shows promise for considerable commercial application and is currently being used against four species of tephritid fruit flies for eight tropical fruits in Hawaii; the Caribbean fruit fly, Anastrepha suspensa (Loew) for guavas in Florida; and the sweet potato weevil, Cylas formicarius elegantulus (Summers) (Coleoptera: Curculionidae), in sweet potatoes also in Florida. ${ }^{71}$ The sweet potato treatment is the first time irradiation has been used on a commercial scale for a commodity in which live adults can be present after irradiation treatment. ${ }^{72}$ Irradiation at the doses used for quarantine treatments does not kill adults quickly but renders them sterile, so inspectors may find live adult insects after an efficacious irradiation quarantine treatment.
The acceptance of this fact on the part of regulatory agencies is a significant step forward in the large-scale commercial application of irradiation.

Basic studies on insect response to quarantine treatments are conducted to understand how variables affect responses. ${ }^{73}$ The early Mexican fruit fly (a nondiapausing tephritid) phanerocephalic pupa (the pupa after eversion of the head) is the stage most tolerant to cold. Of those Tephritidae that undergo diapause, this is the stage that enters diapause. ${ }^{74}$ This could mean that either natural cold tolerance of the early phanerocephalic stage was exploited by tephritids as the stage that developed into the diapausing stage, or that increased cold-tolerance of the phanerocephalic pupa is a relic of earlier development of diapause in the ancestral lineage of the Mexican fruit fly. Thomas and Hallman ${ }^{75}$ found that irradiation of third-instar Mexican fruit fly arrested development at the transition from cryptocephalic to phanerocephalic pupae, suggesting that irradiation damage in this case was due to general irradiation sickness preventing the pupae from achieving the vigorous muscular contractions required to evert the head, instead of radiation-induced atrophy of imaginal discs. Mexican fruit fly inside grapefruit was more radio-tolerant than the insect in vitro, ${ }^{76}$ demonstrating that tests on irradiation quarantine treatments with fruit flies should be done in situ and not in an unnatural environment, such as diet cups. Thomas and Shellie ${ }^{77}$ showed that heating rate affects efficacy of quarantine treatments. The time to achieve the $\mathrm{LT}_{99}$ for Mexican fruit fly at $44{ }^{\circ} \mathrm{C}$ was reduced by one-third when the heating rate of the hot water bath was increased eightfold.

\subsubsection{Pest risk management}

The objective of quarantine treatment efficacy research with fruit flies has been probit 9 (99.9968\%) mortality; it requires treating at least 93613 individuals without survivors. ${ }^{78}$ Probit 9 efficacy was originally recommended for tropical fruits heavily infested with fruit flies and requires high mortality to achieve quarantine security. Although probit 9 may be appropriate or even insufficient for some situations, such as citrus and mango hosts of the Mexican fruit fly from Mexico, ${ }^{79}$ it may be too stringent for quarantine pests in commodities that are rarely infested or are poor hosts. ${ }^{80,81}$

An alternative treatment efficacy approach measures risk as the probability of a mating pair, gravid female or parthenogenic individual surviving in a shipment. This will be a function of many factors, including infestation rate and shipment volume. Applying the risk-based treatment efficacy approach to pests on rarely infested or poor hosts will lower the number of test insects needed for developing quarantine treatments. ${ }^{82}$ For example, rambutan is a poor host for Cryptophlebia in Hawaii. During two seasons, a total of 50 Cryptophlebia adults emerged from 47188 fruits for an infestation rate of $0.0011 .^{83}$ Assuming that a post-harvest treatment provides probit 9 efficacy, 
the probability of $\geq 1$ mating pair surviving in a shipment of 500000 rambutan fruits (9091 shipments) is estimated to be $0.0001 .^{82}$ The required treatment efficacy to prevent the shipment of one mating pair is 99.967\% (probit 9.4). To ensure quarantine security for Cryptophlebia in a shipment of 500000 rambutan fruits or less, approximately 9000 insects must be treated with the proposed treatment with no survivors. Lychee and longan are also poor hosts for Cryptophlebia and amenable to the alternative treatment efficacy approach, as are a number of other hosts of quarantine pests. $^{82}$

\section{RESEARCH HIGHLIGHTS}

\subsection{Tribolium genome mapping project}

Like the Human Genome Project, which may provide information for future solutions to human medical problems, the more we learn about insect genomes, the more opportunities we have for manipulating biochemical processes in insects and developing new types of control technology. Commercial support for part of the Tribolium genome mapping project has come from the Exelixis Pharmaceutical Company, and this interest from industry indicates the great potential for developing future control technologies using genomic methods. New methods have been developed for inserting foreign genes into beetles for the first time. Two 'jumping genes', one derived from a moth and the other from a fly, have been inserted into the chromosomes of the red flour beetle, using new transgene technology, ${ }^{84}$ and this technology is now being tailored and optimized for beetle transgenesis. ${ }^{85}$ These jumping genes can be used to modify, tag or delete target genes in pest insects, to identify insect control genes for insertion into transgenic crops or to insert novel genes into beneficial insects to confer additional desirable traits. The piggyBac transposable genetic element has been modified so that it permits the genetic transformation of both moths and flies. ${ }^{86} \mathrm{~A}$ map of all ten chromosomes of the Tribolium genome has been developed, ${ }^{87}$ and current work focuses on increasing the density of the map and incorporating cDNAs, bacterial artificial chromosomes and other unique sequences. This map has already been utilized for the map-based cloning of several important Tribolium genes and promises to greatly facilitate future efforts at gene localization and targeting.

One of the Tribolium genes successfully obtained via map-based cloning is the maternal larvicidal gene Medea-1 (Maternal Effect Dominant Embryonic Arrest). ${ }^{88}$ In a susceptible genotype, this gene kills larvae as they attempt to hatch from the egg. The lethal effect is maternal, which means that it is actually the mother's Medea gene that causes the death of her own susceptible progeny. The gene is self-protecting, since progeny that are Medea-carriers are insensitive to the maternal lethal effect. This gene is an intriguing candidate for pesticide targeting or pest control exploitation, and it is only the first of several related genes that are being targeted for positional cloning (Beeman, pers comm). Medea genes are also useful for determining population structure and possibly even identifying infestation sources in natural populations of Tribolium. For example, a previously unsuspected regional division of North American populations of $T$ castaneum into northern and southern biotypes was discovered by analysis of Medea- 4 genotypes. ${ }^{89}$

\subsection{Entomological applications of near-infrared spectroscopy}

Immature stages of primary insect pests of stored grain feed exclusively within the grain kernel. Detection of these hidden insects can provide data that can be used to assess the potential population size of an insect infestation and to help make decisions on pest management strategies. For the grain industry, the ability to detect the internal species may also influence decisions on whether or not to purchase a given lot of grain for processing. Despite the concern of the grain industry for economic losses resulting from hidden insect infestations, current detection methods, such as X-ray analysis, are timeconsuming, expensive and generally are not easily automated. To address this problem, Dowell et al $l^{90}$ studied the use of near-infrared spectroscopy (NIRS) for detection of internally feeding species. They used NIRS, automated through a sorting instrument, to scan individual kernels at the rate of one to two per second. With this automated system, older immature stages of three pest species feeding in wheat were detected.

The presence of hidden insects in cereals also increases the fragment count in milled grain, which is a very serious problem in the food industry. PerezMendoza et $a l^{91}$ showed that NIRS can be used to detect and quantify insect fragments in wheat flour. The current NIRS method was not sensitive enough to detect fragments at the FDA (US Food and Drug Administration) action level of 75 fragments in $50 \mathrm{~g}$ of flour, but was able to detect fragments at an action level of 130 fragments in $50 \mathrm{~g}$ of flour. Nevertheless, current NIRS instruments may be useful for prescreening and for selection of flour samples requiring subsequent microscopic analysis. The NIRS system was also used to classify quality of dried figs ${ }^{92}$ and may serve as a means of automating the removal of infested product or as a monitoring tool for optimizing management decisions in dried fruit and nut storages.

In addition to detection of hidden insects, NIRS can be used to identify wheat kernels that contain parasitoids of primary pests developing in the wheat kernels $^{93}$ and can be used for the taxonomic identification of beetle pests of stored grain. ${ }^{94}$ Eleven species were accurately identified using NIRS. These species are all small, dark beetles that can be difficult to identify, especially for pest management personnel that may not be trained in taxonomy. These beetles were identified as primary or secondary pests with 
$>99 \%$ accuracy and were identified to genus with $>95 \%$ accuracy. Identifying these beetles as primary or secondary pests may be sufficient for making pest management decisions.

NIRS also can be used to measure physiological and/or biochemical processes in insects, such as aging. Estimating the age structure of insect populations can be useful for making pest management decisions. NIRS was first used for age-grading short-lived house flies, Musca domestica L (Diptera: Muscidae). ${ }^{95}$ The method was more accurate than the standard method of measuring pteridine accumulation in the heads of Diptera. ${ }^{96}$ This technology has also been successfully applied to long-lived stored-product beetles (PerezMendoza, Throne, Dowell and Baker, unpublished data) and to cockroaches (Perez-Mendoza, Nalyanya, Dowell, Schal, Throne and Baker, unpublished data).

\section{FUTURE RESEARCH}

ARS research on post-harvest entomology will continue to look at basic biological processes in insects that may be exploited for insect control. Most control technologies used today are based on basic biological discoveries made a decade or more ago. Thus, new discoveries made today, such as in insect genomics, will probably be the basis for future insect control technologies. ARS research also will continue on developing practical solutions to today's post-harvest problems. Future research on pests of perishable commodities will focus on detection and delimitation of exotic insect pests, exclusion of exotic insect pests and development of quarantine treatments, control and eradication of exotic insect pests, and fundamental biology and ecology of exotic insect pests. Future research on pests of durable commodities will focus on fundamental biology and ecology of stored-product insect pests, detection and monitoring of stored-product insect pests, development of new and improved control technologies, and development of integrated pest management programs for stored products.

\section{REFERENCES}

1 US Department of Agriculture, National Agricultural Statistics Service (USDA, NASS), Published estimates database: http://www.nass.usda.gov:81/ipedb/ (2000).

2 Cuperus $\mathrm{G}$ and Krischik V, Why stored product integrated pest management is needed, in Stored product management, ed by Krischik V, Cuperus G and Galliart D, Oklahoma State University Cooperative Extension Service Circular E-912, p 199 (1995).

3 Shippy TD, Guo J, Brown SJ, Beeman RW and Denell RE, Analysis of maxillopedia expression pattern and larval cuticular phenotype in wild-type and mutant Tribolium. Genetics 155:721-731 (2000)

4 Brown SJ, Shippy TD, Beeman RW and Denell RE, Tribolium Hox genes repress antennal development in the gnathos and trunk. Molecular Phylogenetics \& Evol 24:384-387 (2002).

5 Howard RW, Miller JS and Stanley DW, The influence of bacterial species and intensity of infections on nodule formation in insects. F Insect Physiol 44:157-164 (1998).
6 Ujvary I, Matolsy G, Belai I, Szurdolsi F, Bauer K, Varjas L and Kramer KJ, Projuvenoids: synthesis and biological evaluation of sulfenylated, sulfinylated, and sulfonylated carbamates. Arch Insect Biochem Physiol 32:659-669 (1996).

7 Baker JE and Kramer KJ, Biotechnological approaches for stored-product insect pest control. Postharvest News Inform $7: 11 \mathrm{~N}-18 \mathrm{~N}(1996)$.

8 Unruh LM, Xu R and Kramer KJ, Benzoquinone levels as a function of age and gender of the red flour beetle, Tribolium castaneum. Insect Biochem Molec Biol 28:969-977 (1998).

9 Huang X, Xu R, Hawley MD, Hopkins TL and Kramer KJ, Electrochemical oxidation of $\mathrm{N}$-acyldopamines and regioselective reactions of their quinones with $N$-acetylcysteine and thiourea. Arch Biochem Biophys 352:19-30 (1998).

10 Kramer KJ, Hopkins TL and Schaefer J, Analysis of intractable biological samples by solids NMR, in Nitrogen-containing macromolecules in the bio- and geosphere, ed by Stankiewicz BA and van Bergen PF, ACS Symposium Series No 707, American Chemical Society, Washington, DC, pp 14-33 (1998).

$11 \mathrm{Zhu} \mathrm{X}$, Zhang $\mathrm{H}$, Fukamizo $\mathrm{T}$, Muthukrishnan $\mathrm{S}$ and Kramer KJ, Properties of Manduca sexta chitinase and its Cterminal deletions. Insect Biochem Molec Biol 31:1221-1230 (2001).

12 Hopkins TL, Starkey SR, Xu R, Merritt ME, Schaefer J and Kramer KJ, Catechols involved in sclerotization of cuticle and egg pods of the grasshopper, Melanoplus sanguinipes, and their interactions with cuticular proteins. Arch Insect Biochem Physiol 40:119-128 (1999).

13 Hopkins TL, Krchma J, Ahmad S and Kramer KJ, Pupal cuticle proteins of Manduca sexta: characterization and profiles during sclerotization. Insect Biochem Molec Biol 30:19-27 (2000).

14 Kerwin JL, Turecek F, Xu R, Kramer KJ, Hopkins TL, Gatlin CL and Yates JR, Mass spectrometric analysis of catechol-histidine adducts from insect cuticle. Anal Biochem 268:229-237 (1999).

15 Huang X, Zhang H, Zen KC, Muthukrishnan S and Kramer KJ, Homology modeling of the insect chitinase catalytic domainoligosaccharide complex and the role of a putative active site tryptophan in catalysis. Insect Biochem Molec Biol 30:107-117 (2000).

16 Kramer KJ, Kanost MR, Hopkins TL, Jiang H, Zhu YC, Xu R, Kerwin JL and Turecek F, Oxidative conjugation of catechols with proteins in insect skeletal systems. Tetrahedron 57:385-392 (2001).

17 Kramer KJ, Muthukrishnan S, Choi HK, Corpuz L and Gopalakrishnan B, Recombinant chitinase and use thereof as a biocide, US Patent 5866788 (1999).

18 Kramer KJ and Muthukrishnan S, Insect chitinases: molecular biology and potential use as biopesticides. Insect Biochem Molec Biol 27:887-900 (1997).

19 Kramer KJ, Muthukrishnan S, Johnson L and White F, Chitinases for insect control, in Advances in insect control: the role of transgenic plants, ed by Carozzi N and Koziel M, Taylor and Francis, Bristol, PA, pp 185-193 (1997)

20 Morgan TD, Oppert B, Czapla TH and Kramer KJ, Avidin and streptavidin as insecticidal and growth inhibiting dietary proteins. Entomol Exp Appl 69:97-108 (1993).

21 Hood EE, Witcher DR, Maddock S, Meyer T, Baszczynski C, Bailey M, Flynn P, Register J, Marshall L, Bond D, Kulisek E, Kusnadi A, Evangelista R, Nikolov Z, Wooge C, Mehigh RJ, Hernan R, Kappel WK, Ritland D, Li CP and Howard JA, Commercial production of avidin from transgenic maize: characterization of transformant, production, processing, extraction and purification. Molec Breed 3:291-306 (1997)

22 Kramer KJ, Morgan TD, Throne JE, Dowell FE, Bailey M and Howard JA, Transgenic avidin maize is resistant to storage insect pests. Nature Biotech 18:670-674 (2000).

23 Kramer KJ, Avidin, an egg-citing insecticidal protein in transgenic corn, in Genetic transformation in crop plants, ed by Liang GH and Skinner DZ, Haworth Press, New York, (in press). 
24 Arbogast RT, Kendra PE, Weaver DK and Shuman D, Insect infestation of stored oats in Florida and field evaluation of a device for counting insects electronically. $\mathcal{F}$ Econ Entomol 93:1035-1044 (2000).

25 Epsky ND and Shuman D, Laboratory evaluation of an improved electronic grain probe insect counter. $\mathcal{F}$ Stored Prod Res 37:187-197 (2001).

26 Shuman D and Crompton RD, Sensor output analog processing - a microcontroller-based insect monitoring system, US Patent Application 09846277 (2001).

27 Mankin RW, Brandhorst-Hubard J, Flanders KL, Zhang M, Crocker RL， Lapointe SL， McCoy CW， Fisher JR and Weaver DK, Eavesdropping on insects hidden in soil and interior structures of plants. F Econ Entomol 93:1173-1182 (2000).

28 Dowdy AK and Mullen MA, Multiple stored-product insect pheromone use in pitfall traps. F Stored Prod Res 34:75-80 (1998).

29 Mullen MA, Wileyto EP and Arthur FA, Influence of trap design and location on the capture of Plodia interpunctella (Indianmeal moth) in a release recapture study. F Stored Prod Res 34:33-36 (1998).

30 Mullen MA and Dowdy AK, A pheromone-baited trap for monitoring the Indianmeal moth, Plodia interpunctella (Hübner) (Lepidoptera: Pyralidae). F Stored Prod Res 37:231-235 (2001).

31 Brenner RJ, Focks DA, Arbogast RT, Weaver DK and Shuman D, Practical use of spatial analysis in precision targeting for integrated pest management. Am Entomol 44:79-101 (1998)

32 Arbogast RT, Kendra PE, Mankin RW and McGovern JE, Monitoring insect pests in retail stores by trapping and spatial analysis. F Econ Entomol 93:1531-1542 (2000).

33 Arbogast RT, Kendra PE and McDonald RC, Infestation of a botanicals warehouse by Plodia interpunctella and Ephestia elutella (Lepidoptera: Pyralidae). Entomol News 113:41-49 (2002).

34 Perez-Mendoza J, Baker JE, Arthur FH and Flinn PW, Effects of Protect-It on efficacy of Anisopteromalus calandrae (Hymenoptera: Pteromalidae) parasitizing rice weevils (Coleoptera: Curculionidae) in wheat. Environ Entomol 28:529-534 (1999).

35 Lord JC, Desiccant dusts synergize the effect of Beauveria bassiana (Hyphomycetes: Moniliales) on stored-grain beetles. f Econ Entomol 94:367-372 (2001).

36 Lord JC, Response of the wasp Cephalonomia tarsalis (Hymenoptera: Bethylidae) to Beauveria bassiana (Hyphomycetes: Moniliales) as free conidia or infection in its host, the sawtoothed grain beetle, Oryzaephilus surinamensis (Coleoptera: Silvanidae). Biol Cont 21:300-304 (2001).

37 Arthur FH, Susceptibility of last instar red flour beetles and confused flour beetles (Coleoptera: Tenebrionidae) to hydroprene. F Econ Entomol 94:772-779 (2001).

38 Oberlander $\mathrm{H}$ and Silhacek DL, Mode of action of insect growth regulators in Lepidopteran tissue culture. Pestic Sci 54:300-322 (1998).

39 Arthur FH, Impact of food source on survival of red flour beetles and confused flour beetles (Coleoptera: Tenebrionidae) exposed to diatomaceous earth. F Econ Entomol 93:1347-1356 (2000).

40 Arthur FH, Immediate and delayed mortality of Oryzaephilus surinamensis (L) exposed on wheat treated with diatomaceous earth: effects of temperature, relative humidity, and exposure interval. F Stored Prod Res 37:13-21 (2001).

41 Throne JE, Doehlert DC and McMullen MS, Susceptibility of commercial oat cultivars to Cryptolestes pusillus and Oryzaephilus surinamensis. F Stored Prod Res 39:213-223 (2003).

42 Throne JE and Eubanks MW, Resistance of Tripsacorn to Sitophilus zeamais and Oryzaephilus surinamensis. F Stored Prod Res 38:239-245 (2002).

43 Mullen MA and Mowery SV, Insect-resistant packaging. Internat Food Hygiene 11(6):13-14 (2000).
44 Johnson JA, Valero KA and Hannel MM, Effect of low temperature storage on survival and reproduction of Indianmeal moth (Lepidoptera: Pyralidae). Crop Protect 16:519-523 (1997).

45 Wang S, Tang J, Johnson JA and Hansen JD, Thermal death kinetics of fifth-instar Amyelois transitella (Walker) (Lepidoptera: Pyralidae) larvae. I Stored Prod Res 38:427-440 (2002).

46 Johnson JA, Vail PV, Soderstrom EL, Curtis CE, Brandl DG, Tebbets JS and Valero KA, Integration of non-chemical, postharvest treatments for control of navel orangeworm (Lepidoptera: Pyralidae) and Indianmeal moth (Lepidoptera: Pyralidae) in walnuts. $\mathcal{F}$ Econ Entomol 91:1437-1444 (1998).

47 Johnson JA, Vail PV, Brandl DG, Tebbets JS and Valero KA, Integration of non-chemical treatments for control of postharvest pyralid moths (Lepidoptera: Pyralidae) in almonds and raisins. F Econ Entomol 95:190-191 (2002).

48 Vail PV, Novel virus composition to protect agricultural commodities from insects, US Patent 5023182 (1991).

49 Johnson JA, Valero KA, Hannel MM and Gill RF, Seasonal occurrence of postharvest dried fruit insects and their parasitoids in a culled fig warehouse. $\mathcal{F}$ Econ Entomol 93:1380-1390 (2000).

50 Maier DE, Adams WH, Throne JE and Mason LJ, Temperature management of the maize weevil, Sitophilus zeamais Motsch. (Coleoptera: Curculionidae) in three locations in the United States. F Stored Prod Res 32:255-273 (1996).

51 Arthur FH, Throne JE, Maier DE and Montross MD, Feasibility of aeration for management of maize weevil populations in corn stored in the southern United States: model simulations based on recorded weather data. Am Entomol 44:118-123 (1998).

52 Arthur FH, Throne JE, Maier DE and Montross MD, Impact of aeration on maize weevil (Coleoptera: Curculionidae) populations in corn stored in the northern United States: simulation studies. Am Entomol 47:104-110 (2001).

53 Arthur FH and Flinn PW, Aeration management for stored hard red winter wheat: simulated impact on rusty grain beetle (Coleoptera: Cucujidae) populations. I Econ Entomol 93:1364-1372 (2000).

54 Throne JE, Hagstrum DW and Nawrot J, A computer model for simulating almond moth (Lepidoptera: Pyralidae) population dynamics. Environ Entomol 27:344-354 (1998).

55 Flinn PW and Hagstrum DW, Simulation model of Cephalonomia waterstoni (Hymenoptera: Bethylidae) parasitizing the rusty grain beetle (Coleoptera: Cucujidae). Environ Entomol 24:1608-1615 (1995).

56 Throne JE, Parajulee MN and Phillips TW, Computer model for simulating population dynamics of the predator Lyctocoris campestris (Heteroptera: Anthocoridae) in stored shelled corn. Environ Entomol 29:1236-1243 (2000).

57 Flinn PW and Hagstrum DW, Stored grain advisor: a knowledge-based system for management of insect pests of stored grain. AI Appl Nat Res Manag 4(3):44-52 (1990).

58 Hagstrum DW, Reed C and Kenkel P, Management of stored wheat insect pests in the USA. Integ Pest Manage Rev 4:127-142 (1999).

59 Hallman GJ, Quarantine treatments: achieving market access for agricultural commodities in the presence of invasive pests, in Invasive arthropods in agriculture: problems and solutions, ed by Hallman GJ and Schwalbe CP, Science Publishers Inc, Enfield, NH, pp 271-291 (2002).

60 US Department of Agriculture, Animal and Plant Health Inspection Service (USDA, APHIS), Treatment Manual, USDA-APHIS-PPQ, Frederick, MD (1998).

61 Follett PA and Lower R, Irradiation to ensure quarantine security for Cryptophlebia spp (Lepidoptera: Tortricidae) in sapindaceous fruits from Hawaii. $\mathcal{f}$ Econ Entomol 93:1848-1854 (2000).

62 Follett PA and Sanxter SS, Hot water immersion to ensure quarantine security for Cryptophlebia spp. (Lepidoptera: Tortricidae) in lychee and longan exported from Hawaii. f Econ Entomol 94:1292-1295 (2001). 
63 Follett PA, Mango seed weevil (Coleoptera: Curculionidae) and premature fruit drop in mangoes. F Econ Entomol 95:336-339 (2002).

64 Follett PA and Gabbard Z, Effect of mango weevil (Coleoptera: Curculionidae) damage on mango seed viability in Hawaii. $\mathcal{F}$ Econ Entomol 93:1237-1240 (2000).

65 Follett PA, Irradiation as a quarantine treatment for mango seed weevil (Coleoptera: Curculionidae). Proc Hawaiian Entomol Soc 35:95-100 (2001).

66 US Department of Agriculture, Animal and Plant Health Inspection Service (USDA, APHIS), Irradiation phytosanitary treatment of imported fruits and vegetables. Fed Reg 65:34 113-34 125 (2000).

67 Jang EB, Nagata JT, Chan HT and Laidlaw WG, Thermal death kinetics in eggs and larvae of Bactrocera latifrons (Diptera: Tephritidae) and comparative thermotolerance to three other tephritid fruit fly species in Hawaii. F Econ Entomol 92:684-690 (1999).

68 Shellie KC and Mangan RL, Postharvest disinfestation heat treatments: response of fruit and fruit fly larvae to different heating media. Postharvest Biol Technol 21:51-60 (2000).

69 Shellie KC and Mangan RL, Cooling method and fruit weight: efficacy of hot water quarantine treatment for control of Mexican fruit fly in mango. HortScience 37:910-913 (2002).

70 Shellie KC and Mangan RL, Hot water immersion as a quarantine treatment for large mangoes: artificial versus cage infestation. F Amer Soc Hortic Sci 127:430-434 (2002).

71 Hallman GJ, Irradiation as a quarantine treatment, in Food irradiation principles and applications, ed by Molins RA, John Wiley \& Sons, New York, pp 113-130 (2001).

72 Hallman GJ, Ionizing irradiation quarantine treatment against sweetpotato weevil (Coleoptera: Curculionidae). Florida Entomol 84:415-417 (2001).

73 Hallman GJ, Factors affecting quarantine heat treatment efficacy. Postharvest Biol Technol 21:95-101 (2000).

74 Hallman GJ, Lethality of cold to third instars, pupae, and pharate adults of the Mexican fruit fly (Diptera: Tephritidae) F Econ Entomol 92:480-484 (1999).

75 Thomas DB and Hallman GJ, Radiation-induced pathology in the metamorphosis of the Mexican fruit fly (Diptera: Tephritidae). F Entomol Sci 35:267-278 (2000).

76 Hallman GJ and Worley JW, Gamma radiation doses to prevent adult emergence from Mexican and West Indian fruit fly (Diptera: Tephritidae) immatures. F Econ Entomol 92:967-973 (1999).

77 Thomas DB and Shellie KC, Heating rate and induced thermotolerance in Mexican fruit fly (Diptera: Tephritidae) larvae, a quarantine pest of citrus and mangoes. F Econ Entomol 93:1373-1379 (2000).

78 Couey HM and Chew V, Confidence limits and sample size in quarantine research. F Econ Entomol 79:887-890 (1986)

79 Mangan RL, Frampton ER, Thomas DB and Moreno DS, Application of the maximum pest limit concept to quarantine security standards for the Mexican fruit fly (Diptera: Tephritidae). F Econ Entomol 90:1433-1440 (1997).

80 Landolt PJ, Chambers DL and Chew V, Alternative to the use of probit 9 mortality as a criterion for quarantine treatments of fruit fly (Diptera: Tephritidae) infested fruit. 7 Econ Entomol 77:285-287 (1984).

81 Vail PV, Tebbets JS, Mackey BE and Curtis CE, Quarantine treatments: a biological approach to decision making for selected hosts of codling moth (Lepidoptera: Tortricidae). f Econ Entomol 86:70-75 (1993).

82 Follett PA and McQuate GT, Accelerated quarantine treatment development for insects on poor hosts. I Econ Entomol 94:1005-1011 (2001).

83 McQuate G, Follett PA and Yoshimoto JM, Field infestation of rambutan fruits by internal-feeding pests in Hawaii. $\mathcal{F}$ Econ Entomol 93:846-851 (2000).

84 Berghammer AJ, Klingler $\mathrm{M}$ and Wimmer EA, A universal marker for transgenic insects. Nature (London) 402:370-371 (1999).

85 Lorenzen MD, Brown SJ, Denell RE and Beeman RW, Cloning and characterization of the Tribolium castaneum eye-color genes encoding tryptophan oxygenase and kynurenine 3monooxygenase. Genetics 160:225-234 (2002).

86 Tamura T, Thibert C, Royer C, Kanda T, Abraham E, Kamba M, Komoto N, Thomas J, Mauchamp B, Chavancy $G$, Shirk P, Fraser $M$, Prudhomme J and Couble P, Germline transformation of the silkworm Bombyx mori $\mathrm{L}$ using a piggyBac transposon-derived vector. Nature Biotech 18:81-84 (2000).

87 Beeman RW and Brown SJ, RAPD-based genetic linkage maps of Tribolium castaneum. Genetics 153:333-338 (1999).

88 Beeman RW and Friesen KS, Properties and natural occurrence of maternal-effect selfish genes (Medea factors) in the red flour beetle, Tribolium castaneum. Heredity 82:529-534 (1999).

89 Beeman RW, Distribution of the Medea factor $M^{4}$ in populations of Tribolium castaneum (Herbst) in the United States. F Stored Prod Res 39:45-51 (2003).

90 Dowell FE, Throne JE and Baker JE, Automated nondestructive detection of internal insect infestation of wheat kernels using near-infrared reflectance spectroscopy. F Econ Entomol 91:899-904 (1998)

91 Perez-Mendoza J, Throne JE, Dowell FE and Baker JE, Detection of insect fragments in wheat flour by near-infrared spectroscopy. F Stored Prod Res 39:305-312 (2003).

92 Burks CS, Dowell FE and Xie F, Measuring fig quality using near-infrared spectroscopy. F Stored Prod Res 36:289-296 (2000).

93 Baker JE, Dowell FE and Throne JE, Detection of parasitized rice weevils in wheat kernels with near-infrared spectroscopy. Biol Cont 16:88-90 (1999).

94 Dowell FE, Throne JE, Wang D and Baker JE, Identifying stored-grain insects using near-infrared spectroscopy. 7 Econ Entomol 92:165-169 (1999).

95 Perez-Mendoza J, Dowell FE, Broce AB, Throne JE, Wirtz RA, Xie F, Fabrick JA and Baker JE, Chronological age-grading of house flies by using near-infrared spectroscopy. $\mathcal{F} \mathrm{Med}$ Entomol 39:499-508 (2002).

96 Tomic-Carruthers N, Robacker DC and Mangan RL, Identification and age-dependence of pteridines in the head of adult Mexican fruit fly, Anastrepha ludens. F Insect Physiol 42:359-366 (1996) 